\title{
Preventing the Illegal Trade of Smuggling Small Arms and Light Weapons (SALW) through UNPoA in Indonesia
}

\author{
Ni Gusti Agung Ayu Mas Tri Wulandari; Putu Eva Ditayani Antari \\ Faculty of Law, Universitas Pendidikan Nasional \\ Corresponding author's email : evaditayaniantari@undiknas.ac.id
}

\begin{tabular}{l}
\hline Article Information \\
\hline Submitted: August 10, 2021 \\
Reviewed : October 17, 2021 \\
Revised : November 01, 2021 \\
Accepted : November 14, 2021 \\
Keywords: \\
countermeasures; illegal \\
firearms; UNPoA \\
DoI: 10.20961/yustisia. \\
v10i3.54717
\end{tabular}

Abstract
Action is needed to combat the illegal trade of Small Arms and
Light Weapons (SALW) because transnational crime is not
easy to commit. However, internal conflicts make Indonesia
more vulnerable to firearms smuggling, considering its
geographical conditions and weak supervision at the border.
Consequently, the government cooperates with neighboring
countries to maintain national integrity and safety. Also, the
government is active in the international regime to deal with
illegal trade of SALW through the United Nations Program
of Action. This study is legal research using primary and
secondary data. The results showed that Indonesia's position
in the United Nations Program of Action helps prevent
firearms smuggling and increase capacity-building assistance.
Furthermore, the government collaborates with the Ministry of
Foreign Affairs and amends and revises Law Number 8 of 1948
concerning Registration and Granting of Permits for the use
of Firearms to prevent illegal trade of SALW. In the regional
scope, similar collaboration is also conducted with Southeast
countries. This is supported by implementing the PoA to Combat
Transnational Crimebyholding the ASEANMinisterial Meeting
on Transnational Crime (AMMTC). In the international scope,
the United Nations Convention Against Transnational Crime
and its three protocols were introduced to eradicate the illegal
trade of SAWL.

\section{Introduction}

Crime always develops according to human civilization from primitive times to modern times. The capability to enter a country without borders is a factor that causes the emergence of modern crime today. Besides that, it is also inseparable from the development of technology and information that is part of life in today's modern society. Even crime no longer exists within the scope of the territory of a country only but can 
go beyond the boundaries of other country territories. Crimes that cross a country's borders are known as transnational crimes, while crimes against transnational in the multilateral scope are called Transnational Organized Crime (TOC). This concept was introduced internationally in the 1990s at the United Nations (UN) meeting, discussing transnational crime prevention.

Transnational crime, or what is known as transnational crime, causes a lot of losses for a country, even for regions certain within the country. Various deviations that can be carried out, such as exploitation (natural resources and human resources) that are too excessive, impact humans in the world. The emergence of problems such as poverty and conflict is one of the causes of transnational crime. Its nature can cross national boundaries and impact other countries, making transnational crime a threat to global security. So, transnational crime is a severe threat to global security and prosperity because it involves several countries (Kementerian Luar Negeri Republik Indonesia, 2019). In 2000, the government issued the United Nations Convention against Transnational Organized Crime to prevent firearms trade. This convention affirmed that an organized criminal group are:

"...more than three persons that exist for a period and act together to commit one or more serious crimes or offenses directly, indirectly, financially or materially..." (article 2 of the United Nations Convention against Transnational Organized Crime)

On 15 November 2000, the UNTOC was adopted by General Assembly Resolution $55 / 25$ to combat transnational crime. This instrument was opened at the high-level Political Conference held in Palermo, Italy, on December 12-15, 2000, and it came into force on September 29, 2003. However, UNTOC only defines crime factors as organized crimes performed across national borders.

UNTOC mentions the characteristics of organized crime groups as:

1. A group consisting of at least three people and formed to perform a task;

2. Exist for a specific time;

3. Come together to commit a crime; and

4. Having a goal to get material directly or indirectly.

Also, the convention mentions transnational elements, including:

1. Conducted in more than one country;

2. Conducted in one country but planned in another;

3. Conducted in one country by syndicates operating in others;

4. Conducted in one country but significantly affect others. (United Nations, 2018)

In conclusion, transnational crimes fail to recognize the territorial boundaries because it has the potential to spread freely and move from one location to another.

Weapons technology is essential for all countries globally, both developed and developing countries. Developed countries use weapons technology to strengthen their influence and position internationally. Meanwhile, developing countries have weapons 
technology to defend national security and state sovereignty from threats from various parties, both internal and external. Internationally, weapons technology can also destroy national security and endanger human safety.

However, "arms smuggling" does emerge as a serious problem and affects regional and international issues. This is because illegal firearms increase crime rates, including damaging development and endangering human security (Rachmanto, 2019). Also, a location becomes influential if surrounded by countries prone to conflict. This makes it easy to smuggle illegal firearms and allows firearms consumers from other countries to smuggle into these conflict-prone countries.

Since the 1990s, the trade of Small Arms and Light Weapons (SALW) has been very cheap in some Southeast regions, including Cambodia, Myanmar, and the Philippines. These firearms are transported to other areas through smaller ships that take the waterways around Thailand, the Philippines, Malaysia, and Indonesia. Allegedly, the increase in trading weapons illegally involves individuals, sub-national groups, and non-state actors.

Generally, light weapons are smuggled in the Southeast region, including Indonesia, because they are legally and illegally used by anyone and are easily transferred among individuals, groups, and countries. According to David Cappie, five factors cause the phenomenon of weapons smuggling in the Southeast Asia region, including(Sitorus, 2008:19):

1. The number of internal conflicts within the country and in line with the needs of the non-state actors against illegal weapons;

2. The fact that there are several post-conflict countries in the region so that several small and multiple weapons can be easily obtained in considerable amount;

3. Southeast Asia is an area with an extended sea area, and smuggling in border areas is challenging to guard and monitor;

4. Whereas the Southeast Asia region consists of several countries belonging to as "weak states." These countries can control their border areas effectively and cannot dispel arms dealers and activities that constitute transnational crimes. These countries also often save legal weapons unsafely, and the facilities are not adequately managed. This then leads to theft, loss, and of course, it is possible for smuggling to occur; and

5. Although the interstate conflict has not occurred in Southeast Asia for more than two decades and regional institutions in the region are well developed, suspicion and mistrust persist in many areas of Southeast Asia. During the Cold War, providing weapons to insurgents in neighboring countries was not included in national policy, which has not been eliminated.

According to Rachmanto (2019), small arms are relatively easy to obtain legally and illegally. However, the illicit trade in Small Arms and Light Weapons is a threat to security and law enforcement because these goods are in the forced displacement of civilians and significant human rights violations while used by corrupt governments, 
organized criminals, or terrorists. According to United Nations Charter and International Humanitarian Law, states have an inherent right to self-defense and use armed force.

In Indonesia, firearms smuggling becomes a threat to territorial integrity because it is used by separatist movements, organized crime groups, and criminals. Furthermore, the illegal trade of SALW disrupts national security and stability. The results showed that inter-state rebel groups, including the Abu Sayyaf, GAM (Free Aceh Movement), and MLF (Moro Islamic Liberation Front), are involved in smuggling and using firearms in Aceh Sulawesi, Maluku, and Papua (Rachmanto, 2019). The illegal trade of SALW is in the form of organized crime because it is an iceberg phenomenon. This is indicated by the recruitment of weapons couriers and orderly transportation to its final destination. Firearms smuggling not only occurs in domestic areas but also crosses national borders on an international scale (Rachmanto, 2019).

Smuggling of firearms or arms smuggling is an iceberg phenomenon. The smuggling of firearms in Indonesia is a form of organized crime. Regularity in smuggling events can be seen through the process of smuggling firearms, starting with the recruitment of weapons couriers, determining transit routes to the destination of weapons smuggling, until the stages of guarding and receiving them to their destination are carried out in a neat and orderly manner. The smuggling of firearms occurs not only in areas of Indonesia (domestic area) but has also crossed national borders internationally.(Rachmanto, 2019)

Conventional crime is a common type of crime that often occurs in society with common motives and backgrounds, such as limited economic capacity. Conventional crimes are committed by various means; one of the most worrying is conventional crimes committed by involving firearms; these crimes are very dangerous because they can target anyone with any background. Some of the crimes that cause concern due to the illegal use of firearms are acts like acts of terrorism to simple acts but have complex motives such as shooting an individual. These crimes often involve firearms as a means. The firearm used for the crime could not have been a registered weapon because it would have been easy for the police to track down. Perpetrators need clean firearms from tracers and have never been registered. Therefore illegal firearms are the foremost choice and a significant need. The need for illegal firearms creates a demand for illegal firearms. The greater demand will increase orders and have an impact on increasing production. All these phenomena will encourage artisans to increase the production of illegal firearms. All of the above statements create a new statement that its top or significantly reduces the number of crimes discussed above; the primary source of support for these crimes must be eliminated, illegal firearms.

Several cases on the internet and documentation from the National Police Headquarters Baintelkam show that the illegal trade of SALW is categorized as transnational organized crime. This is indicated through the transnational and organized crime elements. Meanwhile, transnational elements are the firearms smuggling performed by countries in the Southeast region. At the same time, organized crime involves a group 
or organization with a hierarchical structure to perform this illegal act. It is not easy to factually prove that firearms smuggling is a transnational crime in Indonesia. Therefore, action is needed by the military, police, and intelligence apparatus to combat the illicit trade in SALW (Rachmanto, 2019).

In the United Nations Convention in Palermo, it is stated that Transnational Crime includes money laundering, corruption, illicit trade in protected wild plants and animals, crimes against cultural property, human trafficking, migrant smuggling, and the production and trade of firearms. In this era, various other transnational crimes need to be handled collectively in a multilateral framework, such as theft and smuggling of cultural objects, trafficking in human organs, and environmental crimes (such as illegal logging and illegal fishing), cybercrime identity's-related crimes. Included in the United Nations Convention Against Transnational Organized Crime (UNTOC).

Indonesia is one of the countries interested in the issue of SALW. The circulation and misuse of SALW weapons in several conflict areas are widespread. The following section describes several findings on the illegal circulation of SALW in conflict areas in Indonesia, namely in Maluku, Poso, Aceh, and Papua. Indonesia has a problem with the illegal circulation of SALW. Trafficking of weapons illegally in conflict areas has become a real threat to national security. SALW is not the cause of the conflict but has worsened the conflict. The illegal circulation and use of SALW in conflict areas have threatened Indonesia's national security elements. The fall of civilian casualties and the amount of violence in conflict areas show that the security of individuals and communities has been threatened. Although the above conflicts can be said to have subsided, it does not mean that the threat of SALW has disappeared. This is related to the nature of the SALW type weapon, which can circulate again from one conflict that has ended to the next conflict. If not handled thoughtfully, the illegal circulation of SALW will continue to be a threat to national security.

Previous studies considered the problem of firearms smuggling as a vital issue in a country. This illegal trade has spread within the region because various elements cause it. However, it is concentrated in conflict, violence, war, and organized crime (Panuntut, 2016). Based on the literature review, the role of Indonesia in the United Nations Program of Action (UNPoA) has not been specifically discussed. Therefore, this study examines the country's position in the UNPoA and the government's efforts to prevent firearms smuggling.

\section{Research Method}

This study is normative juridical by conducting secondary data (Soekanto \& Mamudji, 2004). According to Antari (2021), normative legal study helps in providing juridical arguments while there is a void, ambiguity, and conflict of norms. Analytical prescriptive provided suggestions and alternative solutions in overcoming a problem (Sugono, 2011). Data were collected using documentation related to Indonesia's position 
in the United Nations Program of Action and the government's efforts to prevent the illegal trade of Small Arms and Light Weapons. These documents were in the form of books, scientific journals, laws, regulations, and others. The primary legal material used in this study consists of Law Number 8 of 1948 concerning Registration and Granting of Permits to Use Firearms. However, the government strengthened the Emergency Law Number 12 of 1951 concerning the Misuse of Firearms and the Decree of the National Police Chief Number Pol: Skep/82/II/ 2004 dated 6 February 2004 regarding an effective national system in export and import licenses as well as firearms authority to prevent firearms smuggling. The Decree of the National Police Chief is related to Law Number 3 of 2002 concerning the firearms trade and the use of the Arms Trade Treaty. Data were analyzed using a qualitative method to determine the final premise of the study (Moleong, 2005).

\section{Results and Discussion}

\section{A. Transnational Illegal Arms Smuggling as a Transnational Organized Crime}

Philips Jusario Vermonte (2003), in his writings, quotes the opinion of Bunbongkarn, et al. declares that a crime to be accepted as a transnational crime must have two elements, namely as follows:

1. cross-border, whether committed by people (criminals, fugitives, or those who are committing the crime, or victims, as in the case of people smuggling); or by objects (firearms, such as when terrorists put weapons into the plane before takeoff, the money will use in crimes such as illegal drugs); or by intention criminal activities (such as computer fraud in which orders issued in Country A transmitted to Country B); and

2. international recognition of a form of crime. At the level of national, according to the principle of nullum crimen, nulla poena sine lege (none attack, there is no sanction if there is no law), an antisocial act can only be considered a crime if there is a written law that regulates it; whereas at the international level, an action can is considered a criminal act if it is deemed so by at least two countries. This recognition can come from international conventions, treaties, extradition, or the existence of similarities in its national law.

Meanwhile, Harkristuti Harkrisnowo (2004 : 43), in her analysis, concludes that a crime can be said to be an organized crime if the crime:

1. is carried out by more than one person in any well-organized activity

2. built to operate according to an established pattern.

3. bases its activities on more frequent relationships permanent than not.

4. have internally applicable rules and are applied with strict.

5. have a strict hierarchy in a continuous organization and clear division of labor. 


\section{6. profit from crime.}

7. do not hesitate to use coercion, violence, or corrupt efforts to gain immunity.

8. The death does not break the continuity of one of the insider's organizations, and

9. supported by several professional people.

Transnational Organized Crime (TOC) then grows and develops globally. Philips Jusario Vermonte (2003) states that four macro causes drive this: the "dollarization" of the world; emerging forms of identity politics after the Cold War ended; complete access to gain weapons; and the consequences of globalization.

Based on the description above, it can clearly be said that cross-border arms smuggling meets the criteria to be categorized as a TOC. Cross-border arms smuggling is transnational because it enters or removes weapons from one country to another. It involves two or more countries, both as the sender, receiving country, or transit country. The international world has also agreed that arms smuggling is a TOC. This can be seen with the existence of a protocol from the United Nations called the UN Firearms Protocol (2001), which is in addition to The United Nations Convention against Transnational Organized Crime (2000). In carrying out weapons smuggling activities, a TOC group will coordinate it to be well organized, immaculate, and moving stealthily. TOC groups usually set up companies or corporations to disguise the proceeds of their crimes. The most common form of company is import-export, which runs its business both legal and illegal. The legal business is generally running like other companies, which is a shield for their illegal activities (Atmasasmita, 2004 :44).

From the explanation above, it can be concluded that weapons smuggling transnational illegality as a form of transnational organized crime can be said to meet the criteria to be categorized as a TOC. Smuggling cross-border weapons are transnational because they are an activity of importing or removing weapons from one country to another. It involves two or more countries, both as sending countries, countries recipient, or country of transit. The international community has also agreed that arms smuggling is a TOC.

\section{B. Indonesia's Position in the United Nations Program of Action (UNPoA) Regarding Illegal Trade in Small Arms and Light Weapons (SALW)}

The problem of illegal firearms trade, better known as arms smuggling, has emerged as a severe problem among countries and affects regional and even international issues. Because the presence of illegal firearms can affect increasing crime and the situation tends to be unstable both in the country and region, including damaging development and endangering human security. 
Small arms are various killing tools, from handguns to MAN-Portable AirDefense System (MANPADS) because it is portable ammunition designed by the military for individual use. This ammunition includes pistols, rifles, carbines, assault weapons, and submachine guns. Meanwhile, light weapons are heavier and larger than small arms but designed to be used by a minor team or infantry crew. It consists of man-portable ammunition, light artillery guns, rockets, missiles, aircraft, and fortifications. Also, light weapons include heavy machine guns, hand-held under-barrel and mounted grenade launchers, MANPADS, portable anti-tank and rocket launcher systems, as well as mortars under 100 $\mathrm{mm}$ caliber. These weapons are widely produced, easy to hide, and require little maintenance or training (Rachmanto, 2019). In the field of mass destruction, including the Weapon of Mass Destruction (WMD) - nuclear, biological, and chemical, there is no multilateral arrangement to regulate SALW and other conventional weapons. However, in 2000, all UN member states ratified the Program of Action to combat $t$ illegal trade of SALW.

One of the sources of these weapons is from abroad; the problem of illegal SALW can also threaten Indonesia's sovereignty. Considering the illegal circulation of SALW is an issue that crosses national borders (transnational), efforts to overcome it also need to involve other countries. To safeguard its national interests, Indonesia must carry out diplomacy, especially in meetings both at the regional and global levels.

On 9-20 July 2001, the UNPoA enables all countries to come together every six years to improve the firearms regulation, control imports, and exports, implement stockpile management, cooperate, and help themselves. In 2005, the International Tracing Instrument was adopted to regulate the marking, tracing, and recording of firearms/light weapons. However, in 2003, 2005, 2008, 2010, 2012, and 2016, four Biennial Meetings of States (BMS) were held, and the inference in 2006, 2012, and 2018 to implement the UN. In 2001, the adoption of UNPoA and ITI enabled the 2018 3rd conference to be the first meeting that officially produced efforts with a sustainable global agenda and humanitarian issues to eradicate firearms smuggling. Several countries reference global conventional weapons regulations through the Arms Trade Treaty (ATT) that became effective on December 24, 2015. According to Rachmanto (2019), UNPoA is not legally but politically binding because it does not require ratification.

In 2018, the Review Conference ratified the link between UNPoA and ITI with the 2030 Sustainable Development Agenda with 16 Goals and 16.4 Targets to prevent illicit financial flows and trade in SALW. This link is political and functional as an instrument for determining achievement indicators. SDG 2030 was determined through BMS-6 to suggest a national reporting format within the UNPoA and ITI frameworks. 
However, countries' objection to limiting weapons ownership and prohibiting SALW transfer to non-state actors is another issue raised during the conference. The regulation of SALW is inseparable from the trade that has a significant value with lobbying influence. Furthermore, the ATT supporting countries seek to link its relevances as UNPoA and ITI enforcement instruments. On April 2, 2013, the ATT was regarded as an international agreement where the United Nations tried to regulate and limit firearms trade ranging from light to heavy weapons. A total of 154, 3, and 23 countries expressed support, opposed, and abstained from the agreement, respectively. Meanwhile, Indonesia abstained from the agreement, while North Korea, Iran, and Syria expressed their opposition. The country decided to refuse the agreement because several provisions in the ATT are not in line with the inessential position (Panuntut, 2016).

The ATT is trying to regulate the transfer of conventional weapons because it is not used by non-state actors but in conflict areas and the black market. Therefore, Indonesia maximizes the implementation of UNPoA as an international arms regime to combat the illegal trade of SALW.alignsn line with the country's domestic interests that conventional weapons are a real threat to national security. However, most conflicts in Poso, Maluku, Aceh, and Papua were exacerbated by the circulation of illegal trade of SALW. According to Bakrie (2007), UNPoA has become an instrument for UN countries to show their seriousness in preventing and reducing the circulation of illicit weapons because the regulation provided a more comprehensive idea than just to cover arms transfer. This indicates UNPoA is a regime in line with the characteristics of Indonesia's defense interests include, ng imports, weapons development cooperation, and the provisions of the Defense Industry Law.

The country's decision to reject ATT after entry into force affects regulating the conventional arms trade. Meanwhile, Indonesia will be out of the system if it is not an ATT member because non-membership causes the conventional arms trade arrangements to be unaccommodated. The country tends not to be involved in the establishmentestablishingol system as a reporting body (Article 5 ATT). However, it prioritizes its interests by optimizing another conventional weapons regime, including UNPoA. Indonesia plays a vital role in discussing the United Nations Program of Action as an instrument to prevent SALW from circulating on the black market. The UNPoA is an international weapons regime that serves as a guide to overcoming the issue of spreading firearms. In its program, each country is expected to form a national law including manufacturing, storage, transfer, and ownership to combat the illegal trade of SALW. UNPoA is more politically binding because the state is not sanctioned if it failed to comply with the obligated down obligations seriousness of the countries is indicated from the extent to which laws are made to overcome the illegal circulation of SALW 
in their region (Research Cooperation Centre for multilateral policy studies and development, as well as virtuous University 2017).

Then at the Sixth Biennal Meeting of States to Consider the Implementation of the Program of Action to Prevent, Combat and Eradicate the Illicit Trade in Small Arms and Light Weapons in All its Aspects (BMS-6) which was held at the United Nations Headquarters in New York on 6-10 June 2017, Indonesia became a member of the Office of the Bureau as well as Vice-Chair. Indonesia also represents the voices of the Non-Aligned member countries. Indonesia's diplomacy in the UNPoA discussion is indeed quite essential to guard its national interests regarding the issue of SALW. In the BMS6, many delegates linked the implementation of UNPoA with the provisions in the Arms Trade Treaty (ATT). This can endanger the national interest considering Indonesia has not yet ratified the ATT. There are still several provisions in the ATT article that do not support the independence of the Indonesian defense industry. Indonesia is also still facing a real threat of illegal SALW circulation in several areas. Diplomacy in the discussion of UNPoA must be carried out by taking this reality into account.

Indonesia affirmed that UNPoA helped raise international cooperation in preventing firearms smuggling and increasing capacity-building assistance. Furthermore, it encourages the establishment of mechanisms including transborder, cooperation in exchanging information among law enforcement, border, and customs institutions at the regional or sub-regional level.

Indonesia also implements the recommendations of the UNPoA content. Indonesia carries out the implementation through the provision of reports containing: national points of contact, legislation and regulation, stockpile management, collection and disposal, implementation at the regional level, as well as challenges related to the implementation of the PoA, training, and education (Parker \& Green, 2012). In addition, Indonesia's implementation of $\mathrm{UNPoA}$ is through mobilizing cooperation between countries and increasing assistance in capacity building. Furthermore, Indonesia supports international cooperation efforts in eradicating the illicit trade in SALW and encourages the establishment of mechanisms at the regional or sub-regional level, particularly trans-border customs, cooperation in the exchange of information between law enforcement institutions, borders, and customs (Okoro, 2011: 257). It can be seen that Indonesia's implementation of UNPoA includes two things, namely reporting and cooperation between countries in dealing with the illicit trafficking of SALW.

Indonesia is one of the countries that comply with and implement UNPoA to overcome the problem of illegal circulation in its territory. However, the diplomacy carried out is still not supported by SALW arrangements at the national level. Indonesia's laws governing firearms are still unclear (Grillot, 
2010: 149). The existing laws are outdated because most of them are a legacy of colonialism. Regulations regarding transfers are still not clear, even though this process is the most vulnerable because it links the production and ownership of weapons (Marsh, 2013: 178). Weak SALW regulation at the national level will directly impact Indonesia's national security situation.

The country has Law Number 8 of 1948, UU Number 12 of 1951, UU Number 20 of 1960, and Law Number 2 of 2002 that regulate the ownership, licensing, and prohibition of owning firearms. All the Armed Forces and the National Police tend to establish standards in stockpile management. However, no law comprehensively regulates the aspects of registration, marking and tracing, transfer, and brokerage in procurement. Therefore, there is a need for a comprehensive SALW Law, which regulates all aspects of SALW such as storage, registration, marking and tracing brokerage, and transfer.

\section{Indonesia's Efforts in Preventing Illegal Firearms Trade (SALE)}

The trafficking and smuggling of illegal firearms have emerged as a severe problem for the state and regional and even international issues. This is because the presence of illegal firearms can impact increasing crime rates_(Olamide, 2018: 10). The situation tends to be unstable both in the country and the region, including damaging development and endangering human security. Small and small-caliber firearms are challenging to face in monitoring and prosecuting the perpetrators of these crimes because firearms are widespread and can also be used lawfully by civilians and the military.

The problem of the illegal arms trade in Indonesia is more common in conflict areas. Some of the smuggled firearms were used to support the separatist movement in the conflict area, for example, the separatist movement in Aceh and Maluku. The most vulnerable firearm smuggling route in Indonesia is through the territorial waters.

Indonesia has three vulnerable water areas that are often used as a smuggling route for weapons and explosives to support the movement of separatism and acts of terrorism. The three vulnerable points are the Singapore Strait, the Malacca, and the Sunda Strait. In addition, the waters around the Indonesian border with Thailand and the Philippines are also areas prone to smuggling weapons. It is alleged that many weapons are smuggled through traditional routes. Sulawesi waters, especially the Sangihe Talaud border with the Southern Philippines and Nunukan with Tawau Malaysia, are prone to firearms smuggling and explosives to Bitung, Manado, and North Maluku. (Bath, 2021)

Economic factors to obtain financial benefits are the leading cause of arms smuggling. However, apart from economic factors, several other factors also cause weapons smuggling to happen (Bah, 2004: 35). These factors are, among others, due to a large number of conflict areas, a large number of weapons left 
over from the previous conflict, and weak oversightweapons smuggling (Igbini, 2020: 290). These factors are, among others, due to a large number of conflict areas, a large number of weapons left over from the previous conflict, and weak oversight (Oladejo, 2019: 10).

In Indonesia, driving factors directly affect the development of firearms smuggling because it is an archipelago country with an excellent geographical area. These conditions facilitate the transfer of goods with a short distance and time. Therefore, the state experiences difficulties monitoring and controlling a large area while the existing facilities are limited. Inadequate facilities and infrastructure are obstacles to overcoming firearms smuggling. Furthermore, fast boats and other equipment are needed to perform repressive mechanisms, including security patrols. In 2006, the Indonesian National Army was 369,389 consisting of the Army, Navy, and Air Force with 273,693, 68,180, and 27,590. Furthermore, the infrastructure owned by the Army, Navy, and Air Force is 26,649, 639, and 251 units, respectively (Bakrie, 2007). This amount is not proportional to the area of Indonesia while referring to supervisory obligations.

Many efforts have been made to tackle the illegal distribution of weapons at the national, regional, and international legal instruments. However, the existing international agreements and agreements only require the government to oversee future arms transfers so that they do not get out of control and propose monitoring of weapons that have already spread on the market. A crucial aspect of dealing with the illegal arms trade must include eradicating or reducing the demand for weapons.

The Indonesian government has made the Program of Action a guide in preventing the illegal trade in small and light firearms. Moreover, because Indonesia is an official member of the United Nations, Indonesia should ratify and even implement it in prevention efforts at the national, regional, and global levels, including legislation, weapons destruction, weapons storage management, information sharing, and international cooperation.

The Program of Action to Prevent, Combat, and Eradicate the Illicit Trade in Small Arms and Light Weapons in All Its Aspects (also known as the PoA) is an effort by the United Nations to tackle the illegal spread of weapons. This agreement has been ratified by several countries that are committed to carrying out several activities, including the destruction of excess arms stockpiles, DDR (Department of Disarmament Research) programs, support for the suspension of weapons, maintenance of accurate records of weapons manufacturers and owners, and the inclusion of civil society organizations as an effort to prevent the broader proliferation of SALW (Othman, 2019). Although this program (PoA) is not perfect and is still not legally binding, this is the most relevant advocacy tool for the illegal arms trade. 
PoA is divided over recommendations for action taken at national, regional, and global levels. All actions at each level are equally important and mutually exclusive depending on each other (Moses, 2017: 1640). A conducive regional environment is urgently needed for the success of the actions taken on at the national level. Likewise, to support actions taken at the regional level, total commitment is needed to realize concrete actions at the regional level national.

The concern that internal conflicts will spread and be followed by an increasingly globalized world resulting in the development of a modus operandi that will also impact the development of other transnational crimes has become the impetus for Indonesia to take preventive measures (Damaturu, 2020: 157). Not only that, the government is increasingly determined to take preventive measures when the impact is not only capable of shaking the sovereignty of the Republic of Indonesia. But the impact caused by the illegal trade in small and light caliber firearms can threaten human security, state security, and national development. These three threats can be used as a benchmark for the government to continue taking preventive measures to suppress the level of illegal trade in small and light caliber firearms.

This driving factor does not only come from internal factors, but external factors also encourage the Indonesian government to continue carrying out various prevention efforts. The external factor is the pressure of the international community to respect and ensure respect for human rights (Cukier, 2002: 267). This urge is shown by the UN Security Council, which calls on all UN member states to implement the steps recommended in the UNPoA to prevent the widespread illegal trade in small and light firearms.

However, these obstacles are exacerbated by inadequate legal mechanisms and government coordination in dealing with firearms smuggling. This directly affects the effectiveness of law enforcement. Meanwhile, the legislation regarding firearms made after the independent war became a product of the Dutch colonial government because it was challenging to implement. This condition allows various parties to use and import SALW illegally (Panuntut, 2016). The laws and regulations governing these firearms are drawn up separately because no legislation regulates the illegal trade.

Furthermore, there is still a lack of coordination carried out by countries in the Southeast Asian region to overcome the problem of weapons smuggling. The coordination in question can form cooperation mechanisms between countries that regulate the smuggling and trade of illegal weapons. This is because the initial impact was less significant on the country. However, over time there have been changes; the smuggling and illegal trade of firearms (SALW) increasingly exists and becomes a new threat for countries in the Southeast Asian region and countries worldwide in general. 
The smuggling and trafficking of illegal weapons that have emerged in Southeast Asia is a dangerous phenomenon and raises concerns for human security because weapons can accelerate the increase in the number of crimes. Several things make it easy to smuggle and circulate illegal firearms in the Southeast Asia region, namely the location of the region, control over the production, export, and import of weapons, technology in control and supervision, regulations regarding arms trade, supervision in border areas, as well as national government officials. However, there are no international or regional agreements that control the trade in SALW because it is complex and sensitive in regulating. The absence of regional agreements indicated no legal basis for countries to prevent firearms smuggling (Syahmin \& Fidelia, 2015).

Indonesia's seriousness in preventing the illegal trade of SALW is by participating in the United Nations Conference held in 2006 and 2008. In the first conference on 30 June - 7 July 2006, the country showed its agreement with the implementation of UNPoA despite the absence of a comprehensive law that regulates it. Meanwhile, the second meeting held on July 14-18, 2008, indicated that Indonesia follows every national, regional, and global agenda.

In the 2006 UN General Assembly, the country became interested in the Arms Trade Treaty because it affirms the state's right to obtain weapons in selfdefense. Therefore, Indonesia reaffirms the inherent right of an individual and all countries to produce, import, export, transfer and maintain SALW for selfdefense and security needs. The government involvement in the arms trade to acquire military weapons is legal and failed to be impeded. Furthermore, the two things from Indonesia's statement above include: first, it affirms the state's right to self-defense based on Article 51, which correlates with manufacturing, import, export, and transfer of conventional weapons. Second, it asserts that the government involvement in arms trade to acquire military weapons is legal and ideally not hindered.

Indonesia is one country that needs to deal with SALW issues, which is considered threatening domestic and foreign security because it is not adequately monitored (Rachmanto, 2019). Indonesia participates in the ATT because illegal arms transactions that are mostly crossed national borders can threaten domestic security. However, it is challenging to handle cases of illegal transactions which are not accompanied by the eradication of weapons procurement. The government makes comprehensive efforts to prevent firearms smuggling because the conference agreement helped Indonesia protect Human Rights (HAM). Furthermore, the discussion of preventing this problem consists of national, regional, and international issues.

There are three scopes of discussion to tackle the smuggling of illegal firearms, namely national, regional, and international. National efforts made by 
the government are coordinating with various parties to implement the firearms smuggling crime prevention program. The Ministry of Foreign Affairs leads this coordination. It is hoped that this coordination can involve non-governmental organizations as members to carry out their functions more effectively.

The other way to prevent firearms smuggling is by amending and revising Law Number 8 of 1948 concerning Registration and Granting of Permits to Use Firearms. Also, it strengthened Emergency Law Number 12 of 1951 concerning the Misuse of Firearms and the Decree of the National Police Chief Number Pol: Skep/82/II/ 2004 dated 6 February 2004 regarding an effective national system in export and import licenses as well as firearms authority to combat illegal trade of SALW. The Decree of the National Police Chief is related to Law Number 3 of 2002 concerning the regulation of the firearms trade (United Nations, 2005).

Furthermore, the establishment of the Indonesian Sea and Coast Guard (ISCG) as mandated in Law Number 17 of 2008 concerning Shipping is another effort made by the government to prevent firearms smuggling. This country faces many problems at sea because the law enforcement agencies' saddle with the responsibility of preventing this problem is inefficient. Indonesia only adheres to single-task multiagency and not single-agency multi-tasks that lead to losses and waste. In the regional scope, the Southeast countries cooperate to overcome firearms smuggling. This is indicated through the implementation of PoA to Combat Transnational Crime. The objectives of this agency include preventing, controlling, and overcoming, building regional cooperation in the investigation, prosecution, and justice, strengthening the coordination, and developing regional agreements in terms of criminal justice and extradition (Panuntut, 2016). According to United Nations (2005), this implementation is by holding the ASEAN Ministerial Meeting on Transnational Crime (AMMTC).

In the international scope, the government established the United Nations Convention Against Transnational Crime and its three protocols to prevent the trade of Small Arms and Light Weapons. Therefore, a network was built between agencies to accelerate the handling of transnational crimes. On April 20, 2009, UNTOC was ratified by the Indonesian government and stipulated in Law Number 5 of 2009. Implementing the United Nations Convention Against Transnational Crime directly affects law enforcement. In addition, the regulations contained in UNTOC are applied to national law because the convention is of the same degree as other criminal laws (Panuntut, 2016).

\section{Conclusion}

Indonesia's position in the United Nations Program of Action is to support international cooperation efforts in eradicating illegal trade of Small Arms and Light Weapons. Also, it promotes the establishment of mechanisms including trans-border, 
information exchange cooperation among law enforcement institutions, and borders and customs at the regional and sub-regional level. Law Number 8 of 1948, Law Number 12 of 1951, Law Number 20 of 1960, and Law Number 2 of 2002 were established to regulate firearms ownership licensing and prohibition. Furthermore, the Armed Forces and the Indonesian National Police established standards in stockpile management.

The country's efforts in combating the smuggling of Small Arms and Light Weapons include:

a) In the national scope, the government cooperates with various parties and amends and revises Law Number 8 of 1948 concerning Registration and Granting of Permits for the use of Firearms. Also, it strengthens the Emergency Law Number 12 of 1951 concerning the Misuse of Firearms and the Decree of the National Police Chief Number Pol: Skep/82/II/ 2004 dated 6 February 2004 regarding an effective national system in export and import licenses as well as firearms authority. The Decree of the National Police Chief is related to Law Number 3 of 2002 concerning the regulation of the firearms trade.

b) In the regional scope, the Southeast countries cooperate to overcome firearms smuggling. This is realized in the implementation of PoA to Combat Transnational Crime. This implementation is achieved by holding the ASEAN Ministerial Meeting on Transnational Crime (AMMTC).

c) In the international scope, the government made efforts by establishing the United Nations Convention Against Transnational Crime and its three protocols to prevent the trade of Small Arms and Light Weapons. On April 20, 2009, UNTOC was ratified by the Indonesian government and stipulated in Law Number 5 of 2009.

\section{Acknowledgments}

The authors thank the parties that assisted in completing this study. Also, the authors are grateful to lecturers at the Faculty of Law in the National Education University for providing constructive feedback, input, and suggestions.

\section{Bibliography:}

Atmasasmita, R. (2004). Dampak Ratifikasi Konvensi TransnationalOrganized Crime (TOC). Badan Pembinaan Hukum Nasional,Departemen Kehakiman dan Hak Asasi Manusia.

Bah, A. M. (2004). Micro-disarmament in West Africa: the ECOWAS moratorium on small arms and light weapons. African Security Studies, 13(3), 33-46.

Bakrie, C. R. (2007). Pertahanan Negara dan Postur TNI Ideal. In Yayasan Obor Indonesia: Vol. (Issue). 
Bath, A. S. H. (2021). TINJAUAN HUKUM INTERNASIONAL DALAM HAL PENYELUNDUPAN SENJATA ILEGAL DI INDONESIA SESUAI DENGAN UNTOC 2000. Universitas Sumatera Utara.

BolakFunteh, M., \& Oladejo, A. F. (2019). Assessing the Implementation of the Regional Policy on Trafficking in Small Arms and Light Weapons Control in West Africa. Sumerianz Journal of Social Science, 2(1), 1-12.

Chuma-Okoro, H. (2011). Proliferation of small arms and Light Weapons in Nigeria: Legal implications. Law and Security in Nigeria, 255-313.

Cukier, W. (2002). Small arms and light weapons: A public health approach. Brown J. World Aff., 9, 261

Dahari, R., Idris, N. A., \& Othman, Z. (2019). Influencing Factors of Small Arms Light Weapons Smuggling into Malaysia. INTERNATIONAL JOURNAL OF ACADEMIC RESEARCH IN BUSINESS AND SOCIAL SCIENCES, 9(12).

Greene, O., \& Marsh, N. (2013). Governance and small arms and light weapons. In Small Arms, Crime and Conflict (pp. 179-198). Routledge.

Grillot, S. R. (2010). Guns in the Balkans: controlling small arms and light weapons in seven western Balkan countries. Southeast European and Black Sea Studies, 10(2), 147171.

Harkrisnowo, H. (2004). Transnational Organized Crime: Dalam Perspektif Hukum Pidana dan Kriminologi. Indonesian Journal of International Law, 1(2).

Igbini, M. D. (2020). Small arms and light weapons proliferation: Implications for security and sustainable development in Nigeria. International Journal of New Economics and Social Sciences IJONESS, 11(1), 289-296.

Kementerian Luar Negeri Republik Indonesia. (2019). Kejahatan Lintas Negara. Kementerian Luar Negeri Republik Indonesia.

Moleong, L. J. (2005). Metode Penelitian Kualitatif.

Moses, J. M., \& Ngomba, J. L. (2017). Small arms and light weapons proliferation in the early 21st century: The Nigerian case. International Journal of Development and Sustainability, 6(11), 1638-1652.

Olamide, S. A., \& Emmanuel, A. T. (2018). Proliferation of small arms and light weapons: The bane of human security in Nigeria. International Journal of Research Publications, 3(1), 1-12.

Panuntut, M. D. (2016). Analisis Pola Penyelundupan Senjata Small Arms And Light Weapon (SALW) di Indonesia : Studi Kasus GAM Periode 2000-2005. Journal of International Relations. 
Rachmanto, A. S. (2019). Pola Penelundupan dan Peredaran Senjata Api Ilegal di Indonesia. Jurnal Kriminologi Indonesia, V(II), 31-46.

Sambo, U., Damaturu, N., Sule, B., Deribe, A. U., \& Ahmed, A. (2020). The Impact of Small Arms and Light Weapons (SALW) in the Proliferation of Armed Group Conflicts in Northeastern Nigeria: Interrogating the Boko Haram Phenomenon. Arts and Social Sciences, 6(4), 151-161

Sitorus, E. H. (2008). Implementasi Program Aksi PBB dalam Mencegah, Memerangi, dan Menghapus Perdagangan Senjata Ilegal. Universitas Sumatera Utara.

Soekanto, S., \& Mamudji, S. (2004). Penelitian Hukum Normatif Suatu Tinjauan Singkat, Cet. 8 (p. (Jakarta: PT. RajaGrafindo Persada, 2004), h.14).

Sugono, B. (2011). Metode Penelitian Hukum.

Syahmin, H., \& Fidelia. (2015). Strategi ASEAN Dalam Upaya Pemberantasan Penyelundupan Senjata Api Ilegal Dalam Perspektif Un Convention Against Transnational Organized Crime. Seminar Nasional Hasil - Hasil Peneliti Ilmu Hukum, 33-41.

United Nations. (2005). National Report by the Government of Indonesia on the Implementation of the United Nations Programme of Action to Prevent, Combat and Eradicate the Illicit Trade In Small Arms and Light Weapons. United Nations.

United Nations. (2018). United Nations Convention against Transnational Organized Crime. the United Nations.

Vermonte, P. J. (2003). Problematikan Peredaran Small Arms di KawasanAsia Tenggara : Thailand, Filipina dan Indonesia. Jurnal "Analisis CSIS Terorisme dan Keamanan Manusia", XXXII(1). 